\title{
$\mathrm{R}^{\text {juknal }}$ ECHSVINDING
}

\section{ARAH POLITIK HUKUM PERTANAHAN DAN PERLINDUNGAN KEPEMILIKAN TANAH MASYARAKAT}

(Political Direction of Land Law and Protection Of People's Land Ownership)

\author{
Prof. Dr. Nurhasan Ismail, S.H. \\ Guru Besar Fakultas Hukum Universitas Gajah Mada Yogyakarta
}

\begin{abstract}
Abstrak
Penguasaan dan pemanfaatan tanah yang diatur dalam Undang-Undang Pokok Agraria (UUPA) merupakan arah dari politik hukum pertanahan Indonesia yang bertujuan untuk menjamin terwujudnya kemakmuran bagi seluruh rakyat Indonesia. Wujud dari hal tersebut terlihat dari adanya perhatian khusus kepada kelompok masyarakat lemah melalui kebijakan pertanahan. Belakangan, terjadi pergeseran politik pertanahan, dimana penguasaan dan pemanfaatan tanah hanya didapat oleh sekelompok kecil masyarakat, yaitu perusahaan besar. Tulisan yang membahas tentang politik hukum pertanahan nasional saat ini dan bentuk perlindungan hak kepemilikan tanah masyarakat dilakukan dengan metode penelitian sosio-yuridis. Dari hasil penelitian terlihat bahwa pada saat ini terdapat upaya untuk menghidupkan kebijakan pertanahan yang mengembalikan keseimbangan seperti yang diinginkan UUPA. Langkah yang ditawarkan untuk mewujudkan hal tersebut adalah dengan menerapkan politik hukum pertanahan prismatik yang mendasarkan pada beberapa prinsip seperti prinsip keberagaman hukum dalam kesatuan, prinsip persamaan atas dasar ketidaksamaan, prinsip mengutamakan keadilan dan kemanfaatan di atas kepastian hukum, dan prinsip diferensiasi fungsi dalam keterpaduan.
\end{abstract}

Kata Kunci: politik hukum, agraria, hukum prismatik, fungsi sosial, land reform.

\section{Abstract}

Land use and tenure are stipulated in the Basic Agrarian Law (UUPA) is the political direction of the Indonesian land law aimed at ensuring the realization of prosperity for all Indonesian people. Manifestations of this is evident from the presence of particular concern to the community weaker over land policy. Indonesia. Later, the political shift of land, land use and tenure which obtained only by a small group of people, the big companies. Studies that discuss the political current national land law and forms of protection of land rights community do with socio-legal research methods. From the research shows that there are now efforts to turn the land policy that restores the balance as desired UUPA. Measures offered to make this happen is to apply the law of the land prismatic politics based on several principles like the principle of legal diversity in unity, the principle of equality on the basis of inequality, the principle that the justice and expediency over the rule of law, and the principle of differentiation in functionality integration.

Keywords: politic of law, agrarian, prismatic law, social functioning, land reform 


\section{A. Pendahuluan ${ }^{1}$}

“Hidup Tanpa Memiliki Tanah Bagai Makan Tanpa Nasi". Ungkapan tersebut dapat dimaknai sebagai ungkapan "asal omong atau asal bunyi" karena dinilai tidak mengandung makna apapun. Bagi sekelompok orang tertentu, hidup tanpa memiliki tanah sepertihalnya makan tidak harus nasi bukanlah persoalan hidup. Bagi kelompok ini, yang penting bukanlah memiliki tanahnya, namun ada tanah yang dapat disewa dari pemiliknya atau ada tanah kosong tanpa peduli siapa yang mempunyai dan dapat digunakan untuk mendirikan bangunan tempat tinggal atau tempat kegiatan usaha. Bagi kelompok ini juga merasa tidak perlu memiliki tanah namun cukup ada bangunan yang dapat digunakan untuk tempat tinggal atau tempat kegiatan usaha sehingga mereka dapat menjaga keberlangsungan hidup.

Pandangan demikian hanya dianut oleh sebagian kecil umat manusia karena gaya hidup yang nomaden atau karena sikap pesimis terhadap hidup atau sebagai bentuk "pembangkangan" terhadap ketidak-mautahuan negara terhadap keberadaan mereka atau ketidakhadiran negara dalam kehidupan mereka. Namun bagi mayoritas manusia, memiliki tanah seperti halnya makan nasi atau bahan pangan yang mengandung karbohidrat merupakan suatu keniscayaan dan kebutuhan. Memiliki tanah terkait dengan harga diri (nilai sosial), sumber pendapatan (nilai ekonomi), kekuasaan dan hak previlise (nilai politik), dan tempat untuk memuja Sang Pencipta (nilai sakral-budaya). Tidak mempunyai tanah berarti kehilangan harga diri, sumber hidup, kekuasaan, dan tempat penghubung antara manusia dengan Sang Pencipta.

Keniscayaan dan kebutuhan memiliki tanah sudah tertanam sudah sedemikian mendalam dalam lintasan sejarah kehidupan manusia. Hal ini ditunjukkan dalam berbagai ungkapan daerah²: "sakdhumuk batok senyari bumi, yen perlu ditohi pati" atau "ango' apoteya tolang ebanding apoteya mata" atau "uissi la pernah merigat" atau "ulos na so boi maribak".

Ungkapan-ungkapaninimenggambarkan kedudukan dan fungsi tanah yang begitu sangat penting bagi kehidupan manusia. Tanah merupakan sumber penghidupan karena dari tanah mengalir semangat harga diri, kemakmuran, kekuasaan, dan kesakralan. Oleh karenanya, setiap orang berjuang untuk memiliki tanah dan mempertahankannya. Perjuangan tersebut disertai tekad bulat untuk mengorbankan nyawa daripada menanggung malu atau kehilangan harga karena tidak punya tanah.

Menyadari begitu teramat bermakna fungsimemiliki tanah bagi setiap manusia baik

1 Tulisan ini diolah dari makalah yang penulis sampaikan dalam Seminar bertema: "Penyelesaian Sengketa dan Konflik Pertanahan Dalam Perspektif Pembaharuan Hukum Pertanahan Nasional” yang diselenggarakan Badan Pembinaan Hukum Nasional, Kementerian Hukum dan HAM, pada tanggal 17 November 2011.

2 Departemen Penerangan RI, Pertanahan Dalam Era Pembangunan Indonesia, (Jakarta: Ditjen Agraria Departemen Dalam Negeri, 1982) hal. 18. 
dalam kesendiriannya maupun kelompok. Para Pendiri Negara ini sudah menitipkan satu amanah melalui Pasal 33 ayat (3) UUD Negara RI 1945 kepada para penguasa negara Republik Indonesia agar mengatur penggunaan sumber daya alam termasuk tanah untuk meningkatkan kemakmuran seluruh rakyat Indonesia. Sumber daya tanah dan sumber daya alam lainnya bukanlah milik satu golongan tertentu, namun kepunyaan kita semua sebagai bangsa. Kepada negara sebagai organisasi kekuasaan bangsa dibebankan amanah untuk mengatur penggunaan tanah bagi kemakmuran seluruh komponen bangsa dan bukan kelompok tertentu.

Amanah yang tersurat dalam Pasal 33 ayat (3) UUD Negara RI 1945 mengandung dasar dan sekaligus arahan bagi politik pembangunan hukum pertanahan dan sumber daya alam lainnya. Amanah tersebut kemudian dijabarkan dengan semangat yang konsisten dan progresif ke dalam UndangUndang No.5 Tahun 1960 tentang Peraturan Dasar Pokok-Pokok Agraria, yang disebut juga dengan Undang-Undang Pokok Agraria (UUPA). Penjabaran ke dalam UUPA masih dalam tataran asas-asas hukum yang harus dikembangkan ke dalam berbagai peraturan pelaksanaan yang lebih kongkret sehingga dapat lebih operasional untuk meningkatkan kemakmuran seluruh rakyat Indonesia.

Namun seperti dikatakan oleh seorang pemikir Islam bahwa yang paling berat dalam kehidupan adalah melaksanakan amanah. Dalam perjalanan pembangunan politik, politik pembangunan ekonomi, dan lebih khusus politik pembangunan hukum pertanahan, kita sebagai bangsa belum mampu memahami dan melaksanakan isi amanah. Kebijakan pertanahan yang dikembangkan belum sepenuhnya menjabarkan kandungan semangat amanah konstitusi dan UUPA. Akibatnya, bangsa Indonesia semacam terkena "karma" atas pengingkaran amanah berupa konflik hukum dan kepentingan struktural pertanahan yang tidak mereda intensitasnya sampai ungkapan konflik yang paling tinggi berupa tuntutan merdeka seperti yang terjadi di Papua.

Tulisan ini mencoba memberikan gambaran perjalanan arah politik hukum pertanahan yang terjadi secara singkat dan dampaknya dalam aspek tertentu terhadap perlindungan hukum kepemilikan tanah masyarakat.

Dalam perjalanan pembangunan politik, politik pembangunan ekonomi, dan lebih khusus politik pembangunan hukum pertanahan, kita sebagai bangsa belum mampu memahami dan melaksanakan isi amanah. Kebijakan pertanahan yang dikembangkan belum sepenuhnya menjabarkan kandungan semangat amanah konstitusi dan UUPA. Akibatnya, bangsa Indonesia semacam terkena "karma" atas pengingkaran amanah berupa konflik hukum dan kepentingan struktural pertanahan yang tidak mereda intensitasnya sampai ungkapan konflik yang paling tinggi berupa tuntutan merdeka seperti yang terjadi di Papua. 


\section{B. Permasalahan}

Dari uraian di atas, permasalahan yang diangkat dalam tulisan ini adalah:

1. Bagaimana arah politik hukum pertanahan nasional saat ini?

2. Bagaimana dampak politik hukum pertanahan saat ini terhadap perlindungan hak kepemilikan tanah masyarakat?

3. Bagaimana alternatif politik hukum pertanahan di masa depan dalam rangka mengurangi dampak negatif dari politik hukum pertanahan yang ada saat ini?

\section{Metode Penelitian}

Tulisan ini menggunakan pendekatan sosio hukum, dengan maksud ingin melihat lebih jauh daripada sekedar pendekatan doktrinal, sehingga memiliki perspektif lebih luas dengan melihat hukum agraria dalam hubungannya dengan sistem sosial, politik, dan ekonomi masyarakat. ${ }^{3}$

\section{Pembahasan}

\section{Arah Politik Hukum Pertanahan}

Politik hukum pertanahan dalam pengertian pilihan tujuan dan prinsip hukum yang digunakan sebagai pedoman untuk mewujudkan tujuan sudah tertuang dalam UUPA. Di satu sisi, UUPA berkedudukan sebagai penjabaran tujuan dan prinsip hukum dari Pasal 33 ayat (3) UUD Negara RI 1945 namun di sisi lain UUPA beserta prinsipprinsip hukumnya berkedudukan sebagai sumber bagi pengembangan kebijakan dan peraturan perundang-undangan pertanahan nasional. Arahnya adalah untuk menjamin terwujudnya kemakmuran bagi seluruh rakyat Indonesia. Untuk mewujudkan tujuan tersebut, UUPA mengandung prinsip-prinsip penguasaan dan pemanfaatan tanah untuk mendorong kemajuan bidang ekonomi, industri, dan bidang lain yang pelaksanaannya tergantung pada ketersediaan tanah. Namun demikian UUPA juga memberikan perhatian khusus terhadap kelompok masyarakat yang lemah dan termarjinalkan oleh kebijakan pertanahan pada masa sebelumnya.

Dengan pilihan prinsip-prinsip yang dimaksudkan menjamin terwujudnya tujuan tersebut, UUPA dapat ditempatkan sebagai hukum progresif ${ }^{4}$ atau Hukum Prismatik. ${ }^{5}$ Sebagai hukum progresif, UUPA dimaksudkan sebagai instrumen untuk menciptakan suatu perubahan masyarakat yang maju di bidang ekonominya melalui penataan struktur pemilikan tanah, yang di satu sisi mendorong ke arah perubahan pertanian dan industri yang semakin maju namun dengan tidak

Cyberconsult, Reformasi Hukum di Indonesia, Hasil Studi Perkembangan Hukum, (Jakarta: Bank Dunia, 1999), hal. 153.

Satjipto Rahardjo, Hukum Progresif : Penjelajahan Suatu Gagasan, dalam Majalah Newsletter, Kajian Hukum Ekonomi dan Bisnis, Nomor 59, Desember 2004.

5 Nurhasan Ismail, Perkembangan Hukum Pertanahan : Pendekatan Ekonomi-Politik, (Jakarta-Yogyakarta: Huma dan Magister Hukum UGM, 2007) 
mengabaikan keadilan dalam pengertian terciptanya pemerataan pemilikan tanah.

Sebagai hukum prismatik, prinsip-prinsip UUPA dijabarkan dari 2 (dua) kelompok nilai sosial yaitu modern dan tradisional sesuai dengan kemajemukan masyarakat Indonesia. Penjabaran nilai sosial modern tercermin dari prinsip-prinsip: individualisasi kepemilikan hak atas tanah (Pasal 4 jo.Pasal 9 dan pasalpasal hak atas tanah), dorongan pemanfaatan tanah yang dapat menghasilkan produksi yang setinggi-tingginya melalui kewajiban memanfaatkan secara intensif (Pasal 10, Pasal 13, dan Pasal 15), persamaan akses bagi setiap orang untuk mempunyai tanah di seluruh wilayah Indonesia dengan tidak membedakan status kewarganegaraan atau jender (Pasal 4 dan Pasal 9 dan pasal-pasal hak atas tanah), dan pemberian kepemilikan tanah bagi pengembangan usaha berskala besar di sektor pertanian atau industri dengan batasan tertentu (Pasal 28 dan Pasal 35).

Penjabaran nilai sosial tradisional tercermin dari prinsip-prinsip: pelekatan fungsi sosial hak atas tanah dan pembatasan luas tanah yang dapat dipunyai setiap orang sebagai pencegah agar individualisasi kepemilikan tanah tidak mengarah kepemilikan mutlak dan menumpuknya pemilikan tanah pada segelintir orang (Pasal 6 dan Pasal 7 jo.Pasal 17), dorongan ke arah konservasi sumber daya tanah melalui pembebanan kewajiban memelihara kesuburan tanah dan larangan pemilikan tanah absentee sebagai penyeimbang agar tekanan pada produktivitas tanah tidak menimbulkan kerusakan terhadap fungsi dan kemampuan fisik tanah (Pasal 15 dan Pasal 10), pemberian perlakuan khusus kepada kelompok yang lemah dan marjinal dengan membebankan kewajibankepada pemerintah (negara) untuk melindungi golongan ekonomi lemah dan pendistribusian tanah kepada mereka sebagai penyeimbang pada prinsip persamaan beserta semangat persaingan yang mengiringi (Pasal 11 dan Pasal 17), dan pencegahan dominasi dalam penguasaan dan pengusahaan tanah oleh perusahaan dengan kewajiban kegiatan usaha di sektor pertanian dan industri dilakukan dalam wadah koperasi dan larangan monopoli (Pasal 12 dan Pasal 13).

Melalui prinsip-prinsip hukum yang diramu dari perpaduan antara nilai sosial modern dan tradisional dimaksudkan agar pengaturan penguasaan dan pemanfaatan tanah mengarah pada terciptanya kemakmuran yang merata bagi semua orang dan kelompok masyarakat. Melalui perpaduan prinsip-prinsip hukum tersebut, UUPA di satu sisi hendak mendorong kemajuan ekonomi pertanian dan industri dengan memberikan hak atas tanah secara individual kepada setiap orang atau perusahaan dalam skala besar dan mewajibkan kepada mereka berproduksi secara optimal. Namun di sisi lain, UUPA berusaha mencegah terjadinya dampak sosial-ekonomi-politik negatif dari proses pencapaian kemajuan dengan membebankan fungsi sosial hak atas tanah, kewajiban konservasi tanah, perlakuan khusus bagi 
kelompok yang lemah, pewadahan dalam koperasi bagi usaha skala besar, dan larangan monopoli.

Semangat hukum prismatik yang terkandung dalam UUPA, dalam perjalanan pelaksanaannya belum dapat dijabarkan secara utuh baik pada masa Orde Lama maupun Orde Baru dan Orde Reformasi. Pada masa Orde Lama, politik hukum pertanahan sudah mengarah pada upaya mewujudkan pemerataan kemakmuran bagiseluruh rakyat. Melalui program landreform yang sudah diatur dalam UU No.56 Tahun 1960 beserta peraturan pelaksanaannya, perombakan struktur penguasaan tanah yang timpang sudah dimulai dengan mengambilalih tanahtanah kelebihan dari batas maksimum dan tanah-tanah absentee, yang kemudian direncanakan untuk didistribusikan kepada kelompok masyarakat yang tidak mempunyai tanah. Tanah-tanah yang dikuasai langsung negara ditetapkan sebagai obyek landreform untuk didistribusikan kepada masyarakat yang belum mempunyai tanah. Semangat koperasi sebagai wadah pengusahaan tanah dalam skala luas sudah dimulai melalui Peraturan Menteri Agraria dan Pertanian No.11 Tahun 1962 yang menetapkan kepemilikan saham dari perusahaan terbagi menjadi 3 bagian yaitu $50 \%$ tetap dipunyai oleh pendiri perusahaan, $25 \%$ diserahkan kepada karyawan, dan $25 \%$ kepada masyarakat di sekitar tempat beroperasinya perusahaan melalui pemerintah daerah.

Tujuannya jelas, agar terdapat pemerataan penguasaan dan pemilikan tanah sebagai dasar bagi pemerataan kemakmuran dan keuntungan dari perusahaan berskala besar yang dapat dinikmati secara bersama oleh para karyawan dan masyarakat di sekitar perusahaan. Namun demikian, cara dan tujuan yang sudah konsisten dengan UUPA tersebut mengalami kegagalan karena beberapa sebab, yaitu: Pertama, kurang kuat dan konsentratifnya komitmen pemerintah untuk melaksanakan program landreform dan kepemilikan saham perusahaan karena pimpinan negara terlalu sibuk dengan persoalan politik konfrontatif. $\mathrm{Hal}$ ini menyebabkan pemerintah tidak cukup mempunyai kekuatan untuk melawan perlawanan para tuan tanah baik di tingkat pengembangan kebijakan di parlemen melalui partai nasionalis dan keagamaan yang menjadi afiliasi para tuan tanah maupun di tingkat pelaksanaannya, yang tidak rela tanahnya diambil alih untuk dijadikan obyek landreform.

Kedua, kebijakan yang konfrontatif dan revolusioner terhadap terhadap perusahaan berskala besar yang menguasai tanah yang sangat luas terutama yang berstatus perusahaan asing dengan cara melakukan tindakan nasionalisasi. Kebijakan nasionalisasi dilancarkan sejak tahun 1958 sampai 1963 kepada perusahaan asing baik yang bergerak di bidang perkebunan dan sektor perekonomian lainnya. Tanahtanah hasil nasionalisasi itu kemudian tidak dijadikan obyek landreform, namun ditempatkan di bawah pengawasan ABRI. Dalam perkembangannya, sebagian dari 
perusahaan tersebut dikelola oleh ABRI, yang kemudian justru menjadi salah satu sumber konflik pertanahan antara ABRI dengan masyarakat di sekitarnya. ${ }^{6}$

Ketiga, adanya sikaptidakpercaya kepada pemerintah dari salah satu kekuatan partai politik yang ada dan kemudian melakukan tindakan pengambil-alihan tanah secara sepihak dari para tuan tanah. Kekuatan partai politik tersebut kemudian dalam peristiwa Gerakan 30 September 1965 telah dinilai melakukan pemberontakan terhadap negara. Akibatnya, pengambilalihan tanah secara sepihak dinilai juga tidak sah dan di era Orde Baru kemudian diserahkan kembali kepada tuan tanah; Keempat, kemiskinan yang merajalela di akhir pemerintahan Orde Lama yang disebabkan oleh kegagalan program Berdiri Di Atas Kaki Sendiri (BERDIKARI) di semua bidang merupakan faktor penyebab gagalnya arah politik hukum pertanahan di Era Orde Lama.

Pada masa Orde Baru, terjadi perubahan ideologi pembangunan dari sosialisme ala Indonesia yang dikembangkan oleh Soekarno ke arah kapitalisme beserta anak kandungnya berupa liberalisasi dan swastanisasi penguasaan dan pemanfaatan tanah. Pada awalnya, pemerintah Orde Baru masih mempertahankan peranan badan usaha milik negara (BUMN) dalam penguasaan dan pemanfaatan/pengusahaan tanah bagi kegiatan usaha perkebunan dan industri. Liberalisasi dan swastanisasi belum terlalu banyak dikembangkan. Terhadap perusahaan swasta yang sudah diberikan peranan dilakukan pengawasan yang cukup ketat seperti persyaratan pemberian luas tanah disesuaikan dengan "equity capital" atau modal yang dipunyai oleh perusahaan. Hal ini dimaksudkan untuk mencegah terjadinya spekulasi penguasaan tanah dan mencegah terjadinya dampak negatif kepada masyarakat.

Namun dalam perkembangannya, pelan tapi pasti terutama sejak pertengahan dekade 1980'an dan semakin intensif awal 1990'an, swastanisasi dan liberalisasi semakin menjadi mainstream substansi kebijakan pertanahan, bahkan semakin mengarah pada komoditisasi tanah yang berdampak negatif bagi perlindungan kepemilikan tanah masyarakat ${ }^{7}$. Perkembangan tersebut dapat dicermati dari beberapa fakta yaitu :

a. "Pemati-surian" program landreform sebagai instrumen pemerataan kepemilikan tanah. Pemati-surian bermakna adanya kebijakan untuk tidak melaksanakan lagi program landreform (Policy of non Enforcement) meskipun peraturan perundang-undangan yang mengaturnya secara formal tetap

Mohtar Mas'oed, Ekonomi dan Struktur Politik : Orde Baru 1966-1971, (Jakarta: LP3ES, 1989), hal. 60-61.

Ifdhal Kasim, Tanah Sebagai Komoditas: Kajian Kritis Atas Kebijakan Pertanahan Orde Baru, (Jakarta : ELSAM, 1996). 
berlaku. Pemati-surian program landreform ini semakin sempurna ketika dalam masyarakat berkembang persepsi keterkaitan landreform dengan Partai Komunis Indonesia yang sudah dilarang.

b. Adanya kebebasan dan persaingan bagi setiap orang dan badan hukum untuk menguasai dan memiliki tanah serta menempatkan tanah sebagai barang komoditas. Kebebasan menguasai dan memiliki tanah tampak dari: (a) tidak dikembangkannya kebijakan pembatasan kepemilikan tanah bagi tanah pekarangan yang menurut UU No.56 Tahun 1960 diamanahkan untuk diatur; (b) begitu juga perusahaan berbadan hukum mempunyai kebebasan mempunyai tanah seberapa pun luas yang diinginkan meskipun di dalamnya terkandung penguasaan spekulatif yang bertentangan dengan prinsip Pasal 6 UUPA. Baru pada tahun 1999 dengan Peraturan Menteri Negara Agraria/ Kepala BPN No.2 Tahun 1999 tentang Ijin Lokasi dilakukan pembatasan namun luasannya masih cukup tinggi; (c) diabaikannya ketentuan batas maksimum pemilikan tanah pertanian yang sudah ditentukan dalam UU No.56 Tahun 1960; (d) masuknya instansi pemerintah baik secara langsung atau melaluibadan usaha milik negara/daerah yang didirikan menjadi pesaing baru dalam penguasaan dan pemanfaatan tanah melalui Hak Pakai Selamanya atau Hak Pengelolaan yang kemudian dikategorikan sebagai "Barang Milik Negara/Instansi Pemerintah" di luar kepentingan tempat mendirikan kantor atau di luar misi pelayanan publik.

c. Kebebasan menjadikan tanah sebagai barang komoditas dapat dicermati dari: (a) kebebasan memperjual belikan tanah sebagai obyek mendapatkan keuntungan yang sebanyak-banyaknya dari tanah dengan mengabaikan fungsi sosial hak atas tanah sebagaimana diamanahkan Pasal 6 UUPA. Kebebasan ini secara yuridis dibuka kemungkinannya melalui Kepmenpera No.11/KPTS/1994 tentang Pedoman Perikatan Jual Beli Satuan Rumah Susun dan Kepmenpera No.9/ KPTS/M/1995 tentang Pedoman Pengikatan Jual Beli Rumah; (b) pembolehan perusahaan pemegang Hak Guna Usaha untuk menyerahkan pengusahaan tanah kepada perusahaan lain melalui Kontrak Manajemen Pengusahaan atau bentuk yang lain jika praktik demikian sudah menjadi kebiasaan sebagaimana ditentukan dalam Pasal 12 ayat (2) PP No.40 Tahun 1996 tentang HGU, HGB, dan Hak Pakai.

d. Terjadinya persegeseran dari politik pertanahan yang mendorong pemerataan pemilikan tanah sebagai cara mewujudkan kemakmuran rakyat ke arah politik pertanahan yang mendorong ke arah konsentrasi penguasaan dan pemanfaatan tanah pada sekelompok kecil subyek terutama perusahaan besar. Pergeseran ini 


\section{$\mathrm{R}^{\text {juknal }}$ ECHSVINDING}

sejalan dengan logika kapitalisme, yaitu sumberdaya tertentu termasuk tanah tidak perlu didistribusikan kepada sebanyak mungkin orang, namun cukup dikuasai dan dimanfaatkan oleh subyek tertentu yang mempunyai kemampuan mengusahakan baik secara permodalan maupun manajemen dan penguasaan teknologi.

e. Melalui konsentrasi penguasaan dan pemanfaatan tanah oleh perusahaan berskala besar diharapkan terjadi pemerataan kemakmuran melalui ketersediaan lapangan kerja dan upah yang ditentukan dalam bentuk "Upah Minimum Kabupaten/Propinsi" (UMK/P) dengan dasar kebutuhan fisik minimum (KFM) dan bukan kebutuhan hidup minimum (KHM). Berbagai kebijakan dikembangkan untuk mendukung terjadinya konsentrasi penguasaan dan pemanfaatan tanah oleh perusahaan berskala besar ini berupa kemudahan mendapatkan perijinan lokasi (Permennag No.2 Tahun 1993 yang diganti dengan Permennag No.2 Tahun 1999), fasilitas perpajakan, dan termasuk pembiaran hak tradisional masyarakat lokal atau hak ulayat masyarakat hukum adat. Meskipun untuk hak ulayat sudah terdapat kebijakan yaitu Permennag/Ka.BPN No.5 Tahun 1999 yang memberikan perhatian namun aplikasinya oleh pemerintah daerah belum ditindaklanjuti sehingga kebijakan yang populis tersebut tidak mempunyai pengaruh apapun.

f. Ideologisasi pengorbanan oleh rakyat pemilik tanah bagi terujudnya kepentingan negara atau umum. Artinya rakyat pemilik tanah diminta berkorban dengan cara melepaskan hak atas tanah untuk diserahkan kepada pemerintah dengan besarangantirugiyang diinginkan pemerintah meskipun dampaknya bagi kesejahteraan pemilik tanah mengalami penurunan. Demikian semangat yang terkandung dalam Permendagri No.15 Tahun 1975 tentang Pembebasan Hak Atas Tanah Bagi Kepentingan Umum dan Keppres No.55 Tahun 1993 yang menjadi penggantinya.

Pada masa Orde Reformasi sekarang, semangat kebijakan kapitalistik, liberal, dan persaingan tidak mengalami perubahan. Artinya kebijakan pertanahan masih melanjutkan yang sudah ada dan dipraktikkan pada masa Orde Baru, bahkan melalui instansi sektoral kebijakan kapitalistik dan liberal itu semakin meningkat, meskipun Badan Pertanahan Nasional berusaha untuk meredam dan mengembalikannya pada semangat UUPA namun tidak cukup mendapatkan dukungan dari instansi sektoral. Hal ini dapat dicermati dari 2 (dua) kelompok kebijakan, yaitu :

a. Terdapat kebijakan atau rencana kebijakan pertanahan yang dibangun oleh instansi sektoral di luar Badan Pertanahan Nasional yang semakin 
meningkatkan intensitas semangat kapitalistik dan liberal di bidang pertanahan yaitu :

1) rencana kebijakan Kementerian Pertanian yang akan membuka jutaan hektar tanah untuk pertanian pangan melalui "Food Estate Program". Pemerintah dalam rangka menjamin ketahanan dankedaulatan pangan berencana membuka tanah pertanian baru, namun penguasaan dan pemanfaatannya akan diberikan kepada perusahaan berskala besar dan bukan didistribusikan kepada warga masyarakat petani. Artinya, kebijakan ini memang merupakan kelanjutan dari kebijakan konsentrasi penguasaan dan pemanfaatan tanah yang sudah dikembangkan di masa Orde Baru. Sebaliknya kebijakan ini memang sudah mengabaikan semangat pemerataan pemilikan tanah pertanian yang dikehendaki oleh dasar politik pertanahan yaitu UUPA;

2) masih dalam rangka menjamin ketahanan dan kedaulatan pangan, pemerintah melalui badan usaha milik negara berencana untuk menyewa tanah pertanian yang dipunyai petani untuk diusahakan tanaman pangan. Di satu sisi rencana kebijakan ini menunjukkan kepedulian pemerintah terhadap kebutuhan pokok masyarakat, namun di sisi lain rencana tersebut menunjukkan semangat liberal pemerintah dengan tidak ingin membina petani agar mampu berproduksi lebih optimal lagi;

3) pemberian perlindungan kepada penguasaan dan pemanfaatan tanah oleh perusahaan perkebunan berskala besar dari kemungkinan terjadinyatuntutanataupendudukan tanah atau gangguan terhadap kegiatan usaha oleh siapa pun dengan cara kriminalisasi terhadap setiap gangguan kegiatan usaha perkebunan. Hal ini ditentukan dalam Pasal 21 UU No.18 Tahun 2004 tentang Perkebunan. Di satu sisi, ketentuan Pasal 21 tersebut bertujuanuntukmenjaminkepastian dan perlindungan hukum bagi setiap perusahaan perkebunan yang sudah mendapatkan ijin dan HGU. Namun di sisi lain, ketentuan dapat menjadi ancaman bagi warga masyarakat hukum adat yang atas dasar hak ulayatnya untuk memanfaatkan tanah yang sama namun belum mendapatkan rekognisi apapun bagi penggunaan tanah oleh perusahaan perkebunan.

4) Melalui UU Rumah Susun yang baru disahkan oleh DPR, pemerintah didorong untuk melanjutkan semangat liberalisasi penguasaan dan pemanfaatan tanah dengan cara memperkuat kepemilikan tanah oleh orang asing baik untuk 


\section{$\mathrm{R}^{\text {juenal }}$ ECHSVINDING}

ditempati maupun sebagai sarana investasi. Dengan kebijakan demikian, pemerintah dinilai seakan-akan terhormat di mata investor asing. Namun yang sebenarnya, pemerintah menjadi tidak terhormat di mata warga negaranya sendiri karena begitu sangat sulitnya warga negara menengah ke bawah mendapatkan tanah bagi bangunan Rumah Susun Sederhana/Bersubsidi.

5) Semakin intensifnya semangat liberalisme di kalangan instansi pemerintah atau pemerintah daerah menguasai dan memanfaatkan tanah di luar pelayanan publik yaitu bagi kegiatan usaha. Hal ini dilakukan dengan memanfaatkan Hak Pakai Selamanya atau Hak Pengelolaan yang dipunyai untuk digunakan sebagai sumber pendapatan. Pemanfaatan demikian dimungkinkan oleh UU No.1 Tahun 2004 tentang Perbendaharaan Negara dan PP No.6 Tahun 2006 tentang Pengelolaan Barang Milik Negara/Daerah. Di satu sisi, kebijakan tersebut membuka kemungkinan diperolehnya peningkatan pendapatan pemerintah/ pemerintah daerah sebagai sumber pembiayaan pembangunan. Dari sisi lain, kebijakan tersebut justru telah menempatkan pemerintah/ pemerintah daerah sebagai "pesaing" warga negara untuk mendapatkan tanah. Pemerintah/ pemerintah daerah seharusnya menjadi fasilitator dan advokator agar setiap warga negara dapat mempunyai tanah. Namun dengan kedudukan sebagai pesaing, bukan tidak mungkin nantinya, justru warga negara harus menyewa tanah untuk tempat tinggal atau kegiatan usaha dari pemerintah/ pemerintah daerah seperti yang terjadi pada zaman kolonial.

b. Di tengah-tengah meanstream politik pertanahan yang kapitalistik dan liberal tersebut, Badan Pertanahan Nasional (BPN) berusaha untuk menghidupkan kebijakan pertanahan yang mengembalikan keseimbangan seperti yang diinginkan UUPA. Namun demikian, kebijakan tersebut tidak cukup mendapatkan dukungan dari instansi sektoral lainnya termasuk oleh aparat penegak hukum. Kebijakan yang dimaksud yaitu :

1) Penyusunan RPP Reforma Agraria yang sudah dimulai pada awal pemerintahan SBY, namun RPP ini tampaknya tidak berlanjut dan tidak terdengar lagi beritanya. Kendalanya dapat ditebak yaitu Reforma Agraria yang sebenarnya dapat menjadi sarana untuk meningkatkan produksi pertanian dengan tetap menjunjung tinggi 
pemerataan pemilikan tanah, dinilai menjadi faktor penghambat bagi pengembangan usaha perkebunan atau pertanian berskala besar yang kapitalistik dan liberal. Penilaian demikian sebenarnya sudah dikembangkan dan ditanamkan sejak Orde Baru.

2) Pemberlakuan PP No.11 Tahun 2010 tentang Penertiban dan Pendayagunaan Tanah Terlantar sebagai pengganti PP No.36 Tahun 1998. PP ini di satu pihak mengandung politik pertanahan yang akan menertibkan tanah terlantar perusahaan yang mencapai jutaan hektar dengan kerugian negara mencapai triliunan rupiah. Di pihak lain, BPN berniat untuk menempatkan tanah terlantar tersebut sebagai obyek landreform sehingga mendorong terjadinya pemerataan tanah pertanian / perkebunan. Namun demikian, PP yang sedemikian populisnya ini kehabisan kekuatan menghadapi perlawanan baik instansi sektoral pendukung liberalisasi dan spekulasi penguasaan tanah maupun perusahaan berskala besar yang mempunyai kekuatan pengaruhyang sangat tinggi dalam pelaksanaan kebijakan.

3) Perpres No. 36 Tahun 2005 tentang PengadaanTanahUntukKepentingan Umum dan perubahannya dalam
Perpres No.65 Tahun 2006. Perpres ini sebenarnya mengandung semangat untuk menyeimbangkan antara kepentingan pemilik tanah yang akan diambil dengan kepentingan umum yang diwakili oleh instansi pemerintah sebagaimana dikehendaki oleh Pasal 6 dan Pasal 18 UUPA. Upaya penyeimbangan kepentingan tersebut dilakukan melalui keseimbangan hak dan kewajiban. Pemilik tanah wajib menyerahkan tanahnya jika sungguh-sungguh diperlukan bagi kepentingan umum, namun pemerintah wajib memberikan ganti rugi yang layak untuk menjamin keberlangsungan kesejahteraan pemilik tanah.

Namun semangat keseimbangan dalam Perpres tersebut tidak mampu melawan "Ideologisasi pengorbanan Rakyat Demi Kepentingan Umum" yang sudah ditanamkan sejak Orde Baru. Artinya rakyat diharuskan untuk berkorban untuk kepentingan umum termasuk harus menerima jika pengorbanan itu menuntut mereka dalam kondisi miskin. Di samping itu, semangat keseimbangan tersebut harus menghadapi satu bentuk perlawanan baru yaitu kriminalisasi atau korupsisasi oleh Penegak Hukum terhadap setiap pembayaran ganti rugiyang melampaui Nilai Jual Obyek Pajak (NJOP) padahal NJOP menurut Perpres hanyalah pedoman awal dalam pelaksanaan musyawarah yang akan menentukan besarnya ganti rugi 


\section{$\mathrm{R}^{\text {juknal }}$ ETSVINDING}

yang sebenarnya dan pembayaran ganti rugi terhadap setiap kepemilikan tanah yang tidak bersertipikat meskipun mereka sudah menempati tanah puluhan tahun sebagaimana ditentukan dalam PP No.24 tahun 1997 tentang Pendaftaran Tanah. Jika kriminalisasi atau korupsisasi terus berlanjut, maka penegakan hukum telah menjadi kekuatan baru bagi proses marjinalisasi dan kemiskinan warga negara pemilik tanah yang terkena pengadaan tanah dan belum bersertifikat .

\section{Dampak Politik Hukum Pertanahan Terhadap Perlindungan Hak Kepemilikan Tanah Masyarakat}

Arah dan prinsip politik hukum pertanahan yang berlangsung sampai sekarang seperti yang digambarkan di atas telah berkontribusi terhadap berbagai persoalan sosial-ekonomi dan politik, yaitu :

a. Konflik kewenangan antar instansi pemerintah yang terkait dengan pertanahan yaitu BPN di satu pihak dengan Kementerian Kehutanan, Kementerian Pertanian dan kementerian terkait lainnya. Sumber konfliknya adalah perbedaan cara dalam mewujudkan amanah Pasal 33 ayat (3) UUD Negara RI 1945. Di satu pihak terdapat kebijakan yang mengembangkan cara pemerataan penguasaan dan pemanfaatan tanah untukmewujudkan kemakmuran seluruh komponen rakyat, sedangkan yang lain mengembangkan cara konsentrasi penguasaan dan pemanfaatan tanah untuk mewujudkan arah politik hukum pertanahan tersebut.

b. Arah dan prinsip politik hukum pertanahan yang kapitalistik dan liberal yang digunakan selama ini memang di satu sisi telah menimbulkan kemajuan dalam pembangunan sektor perkebunan dan properti di Indonesia. Namun di balik keberhasilan atau dampak positif tersebut, politik hukum pertanahan juga telah mendatangkan dampak sampingan negatif. Di antara dampak sampingan negatif adalah :

1) terjadinya kesenjangan dalam penguasaan dan pemanfaatan sumberdaya alam berupa tanah. Dengan kata lain, ada ketimpangan dalam distribusi penguasaan dan pemilikan tanah. Ada sekelompok kecil subyek menguasai dan memanfaatkan tanah yang sangat luas/besar, namun sebagian besar warga masyarakat hanya menguasai dan memanfaatkan bagian sumberdaya yang relatif terbatas. Secara umum, tingkat kesenjangan semakin meningkat seperti ditunjukkan oleh Indeks Gini sebesar 0,308 pada tahun 1999 dan 0,363 pada tahun $2005 .^{8}$ Data

8 Joyo Winoto, Mandat Politik, Konstitusi dan Hukum Dalam Rangka Mewujudkan Tanah Untuk Keadilan dan Kesejahteraan Rakyat, tulisan yang disampaikan dalam Kuliah Umum di Balai Senat Universitas Gadjah Mada, Bulaksumur - Yogyakarta, 2007, hal. 5. 
di bidang pertanahan menunjukkan bahwa $0,2 \%$ dari penduduk Indonesia menguasai sekitar 56\% aset berupa properti, perkebunan, dan tanah pertanian ${ }^{9}$, sehingga ada $99,80 \%$ penduduk Indonesia yang harus bersaing menguasai dan memanfaatkan sisanya sebesar 44\%. Data lain di bidang pertanian menunjukkan bahwa pada tahun 2003 sebanyak 70\% rumah tangga petani hanya menguasai tanah pertanian rata-rata sebesar 0,17 Ha. ${ }^{10}$ Sebaliknya ada $10 \%$ penduduk pedesaan yang menguasai $55,3 \%$ tanah pertanian ${ }^{11}$.

Bahkan jika dibandingkan dengan sektor perkebunan kelapa sawit, setiap perusahaan rata-rata menguasai $7.500 \mathrm{Ha} .{ }^{12}$

Data kuantitatif di atas memang tidak mutakhir, namun secara kualitatif kesenjangan khususnya di perkotaan dapat dicermati dari fakta, yaitu:(1)betapasulitnyamemperoleh tanah bagi pembangunan rumah susun milik atau rumah susun sewa yang diperuntukkan bagi kelompok masyarakat berpenghasilan rendah, namun sebaliknya begitu sangat mudahnya perolehan tanah untuk membangun rumah mewah atau menegah bagi kelompok masyarakat menengah-atas ${ }^{13}$;

(2) sulitnya kaum miskin perkotaan mendapatkan ruang tempat berusaha, bahkan tempat usaha kecilatau pasar tradisionalyang sudah ada mengalami kemandegan atau penggusuran ${ }^{14}$. Sebaliknya penyediaan ruang tanah bagi pasarpasar modern seperti mall atau bisnis ritel dan bagi pembangunan kantor pemerintah dengan mudah dapat disediakan ${ }^{15}$. Pelan tapi pasti kemudahan itu telah menggusur dan meminggirkan kelompok miskin perkotaan dan pedagang tradisional ${ }^{16}$.

(3) sempitnya ruang pedestarian bagi pejalan kaki atau pesepeda karena ruang lalu lintas hanya diperuntukkan bagi kendaraan

$9 \quad$ webugm@ugm.ac.id, Ketimpangan Kepemilikan Aset Sebagai Penyebab kemiskinan, (Yogyakarta: Universitas Gadjah Mada, 2008).

10 Zulfadhli, H, Tanah Untuk Petani, tulisan yang disampaikan dalam Seminar Nasional HKTI "Reforma Agraria, Pelaksanaan otonomi Daerah, dan Penataan Ruang, 2009; lihat juga Iwan N. Selamat, Ketimpangan Struktur Agraria Indonesia, 2009.

11 Khudori, Petani, Kemiskinan, dan Reforma Agraria, dalam Kompas, Jakarta, 16 Maret 2007.

12 NN, Palm Oil Problem : Plantation Companies in Conflict With Villagers, Tuesday, May, 19 ${ }^{\text {th }}$, dalam The Jakarta Post, Jakarta, 2009, hal. 5.

13 Eko Budihardjo, Mitropolis atau Miseropolis, dalam Kompas, Jakarta, Sabtu 22 September 2007, hal. 6.

14 Lucinda, Di Tengah Kepungan Bisnis Ritel, dalam Harian Bernas, Yogyakarta, tanggal 18 Mei 2010, hal. 4.

15 Kompas, 2008, Tajuk Rencana : Kasus dan Penggusuran, Sabtu 26 Januari, hal. 6.

16 Patrick McAuslan, Tanah Perkotaan dan Perlindungan Rakyat Jelata, (Jakarta: PT Gramedia, 1986), hal. 16. 
pribadi. Konsekuensinya, pejalan kaki atau pesepeda harus berjalan di ruang pedestarian yang sempit atau menggunakan bagian pinggir badan jalan dengan resiko tertabrak kendaraan bermotor.

2) realitas kemiskinan masih menjadi problem bangsa Indonesia. Jika diukur dengan patokan angka garis kemiskinan yang digunakan Pemerintah pada tahun 2010 yaitu sebesar Rp 211.726,- perkapita/ perbulan, maka pada tahun 2010 masih terdapat $13.33 \%$ atau 31.02 juta orang miskin. ${ }^{17}$ Jumlah orang miskin akan semakin tinggi lagi jika memasukkan orang yang memperoleh penghasilan tepat pada angka garis kemiskinan atau menggunakan angka garis kemiskinan yang ditetapkan Perserikatan Bangsa-Bangsa yaitu sebesar US\$ 3 atau sekitar Rp 750.000,- $\quad$ perkapita/perbulan. ${ }^{18}$ Terlepas dari pro-kontra kriteria dan jumlah orang miskin, jumlah orang miskin di beberapa daerah berada di atas rata-rata angka kemiskinan nasional yaitu mencapai $2-3$ kali lipat. Sebagian besar orang miskin itu berada di daerah pedesaan yaitu mencapai 64,23 pada tahun 2010. Sebagian daerah yang menjadi kantong-kantong kemiskinan tersebut mempunyai sumberdaya alam yang relatif miskin, namun sebagian lainnya berada di wilayah yang mempunyai sumberdaya alam yang sangat kaya. Kantong kemiskinan yang terdapat di daerah yang miskin sumberdaya alam masih dapat dipahami meskipun itu menunjukkan kurang maksimalnya pelaksanaan tanggungjawab negara. Sebaliknya, suatu keprihatinan besar dan pertanyaan mendasar harus dikemukakan terhadap kantong kemiskinan yang terdapat di daerah yang sangat kaya sumberdaya alam seperti di Papua, Kalimantan, dan Sumatera termasuk di wilayah pesisirnya.

3) Politik hukum pertanahan juga telah mendorong terjadinya konflik struktural antar kelompok subyek yaitu :

(a) berlangsung dan berkembangnya konflik struktural yang dipicu oleh kebijakan negara yang mendorong terjadinya kesenjangan sosial ekonomi dan kemiskinan di daerah yang sangat kaya sumberdaya alam. Konflik struktural itu melibatkan kelompok masyarakat lokal baik atasdasarkebutuhandanhistoris

Berita Resmi Statistik, Profil Kemiskinan Di Indonesia 2010, dalam Berita Resmi Statistik No.45/07/Th XIII, (Jakarta: Badan Pusat Statistik, 1 Juli 2010).

18 Kompas, 2011, Kemiskinan Tampak Nyata, Senen, 15 Agustus, hal. 15. 
mempunyai keterkaitan dengan obyek konflik, para pelaku usaha atau investor yang memperoleh akses dan aset dalam skala besar, dan pemerintah atau pemerintah daerah sebagai pelaksana kewenangan negara dalam pembuatan kebijakan dan pendistribusian akses dan aset. Jumlah dan intensitas konflik terus berlangsung sejalan dengan rendahnya tingkat harapan masyarakat akan kemungkinan terjadinya perubahan kebijakan yang akan memberikan perlindungan hukum terhadap akses memperoleh tanah atau hak atas tanah. Akibatnya masyarakat lokal dalam kondisi tanpa harapan akan adanya perubahan mengungkapkannya dalam bentuk-bentuk konflik. Semula bentuk konfliknya hanya tindakan "reclaiming" terhadap hak historis atau hak konstitusional mereka atau tindakan pendudukan lokasi-lokasi yang menjadi obyek konflik. Namun ketika bentuk konflik tersebut tidak mendapatkan respon positif dari negara, konfliknya berubah menjadi tindakan kekerasan seperti yang terjadi di Pasuruan, Kebumen, Lampung, Sumatera
Utara, Kalimantan, Sulawesi Barat, Nusa Tenggara Barat, dan Papua. Puncak konflik berupa tuntutan pemisahan diri atau keluar dari ikatan Negara Kesatuan RI seperti yang pernah terjadi di Aceh serta yang sudah dan terus berlangsung di Papua.

(b) Konflik struktural antara pemilik tanah yang terkena pengadaan tanah untuk kepentingan umum dengan instansi pemerintah yang memerlukan tanah. Konflik ini akan terus berlangsung karena di satu sisi pemilik tanah merasa tidak mendapatkan perlindungan hukum terhadap hak-hak individunya dengan rendahnya ganti rugi yang diberikan. Namun di sisi lain, instansi pemerintah didorong untuk mencari cara untuk mempercepat perolehan tanah termasuk cara yang represif seperti konsinyasi ganti rugi ke Pengadilan meskipun tanpa persetujuan pemilik tanah tanpa berupaya memenuhi harapan pemilik tanah mendapatkan ganti rugi yang menjamin keberlangsungan kesejahteraan mereka sebagaimana dikehendaki oleh Perpres No.36 Tahun 2005. 


\section{$\mathrm{R}^{\text {juknal }}$ ECHSVINDING}

\section{Alternatif Politik Hukum Pertanahan}

Untuk mengurangi atau bahkan meniadakan dampak negatif dari politik hukum pertanahan yang ada, maka perlu pemikiran untuk mengembangkan politik hukum pertanahan yang "prismatik". Arah politik hukum pertanahan prismatik ini dimaksudkan untuk mewujudkan dan mendorong kemajuan perekonomian Indonesia melalui penataan penguasaan dan pemanfaatan tanah namun tetap memberikan perhatian terhadap kelompok yang lemah secara sosial-ekonomi-politik dengan memberikan akses kepada mereka mempunyai tanah. Untuk mewujudkan tujuan tersebut, politik hukum pertanahan prismatik mendasarkan pada prinsip hukum tertentu sebagai dasar pengembangan kebijakan pertanahan, yaitu :

a. Prinsip keberagaman hukum dalam Kesatuan;

Prinsip ini menekankan pada penghormatan terhadap perbedaan hukum yang terdapat dalam masyarakat di bidang pertanahan khususnya dengan memberikan pengakuan dan penghormatan terhadap kewenangan pemerintahan masyarakat hukum adat sebagaimana dikehendaki oleh Pasal 18B ayat (2) UUD Negara RI 1945. Namun pengakuan dan penghormatan tersebut harus sesuai dengan kepentingan bangsa dan negara sebagai konsekuensi dari komitmen kebangsaan yang sudah kita sepakati. b. Prinsip persamaan atas dasar ketidaksamaan;

Prinsip ini menekankan bahwa untuk mewujudkan adanya persamaan secara sosial ekonomi terutama di masyarakat majemuk seperti Indonesia harus dikembangkan kebijakan pertanahan yang mendasarkan pada realita ketidaksamaan (perbedaan) di antara kelompok-kelompok masyarakat. Bagi kelompok yang sudah mampu, dapat mempunyai tanah berdasarkan persyaratan dan prosedur yang umum berlaku. Namun bagi kelompok yang lemah harus ada intervensi negara untuk memberikan kemudahan dan fasilitas pemberian tanah. Dengan adanya perbedaan perlakuan tersebut, semua kelompok akan mencapai persamaan kondisi sosial ekonomi.

c. Prinsip mengutamakan keadilan dan kemanfaatan di atas kepastian hukum;

Prinsip ini menekankan bahwa mewujudkan pemerataan penguasaan dan pemilikan tanah merupakan kebijakan yang lebih memenuhi rasa keadilan dan kemanfaatan bagi masyarakat. Berdasarkan prinsip ini, menumpuk penguasaan dan pemanfaatan tanah merupakan tindakan yang tidak adil dan tidak bermanfaat karena hanya menimbulkan kecemburuan sosial dan penelantaran tanah yang merugikan kepentingan bersama. 
d. Prinsip diferensiasi fungsi dalam keterpaduan;

Prinsip ini menekankan bahwa di satu sisi pembagian kewenangan di antara instansi pemerintah merupakan suatu kebutuhan untuk terjadinya efektivitas pencapaian tujuan bersama. Oleh karenanya harus dicegah terjadinya egoisme sektoral yang menyebabkan terjadinya hambatan terhadap pencapaian tujuan bersama. Untuk itu, keterpaduandiantarainstansipemerintah menjadi keniscayaan agar kebijakan yang dikembangkan tidak saling tumpangtindih dan saling menafikan.

\section{E. Penutup}

\section{Kesimpulan}

a. Arah politik hukum pertanahan pada awalnya adalah untuk menjamin terwujudnya kemakmuran bagi seluruh rakyat Indonesia. Untuk mewujudkan tujuan tersebut, UUPA mengandung prinsip-prinsip penguasaan dan pemanfaatan tanah untuk mendorong kemajuan bidang ekonomi, industri, dan bidang lain yang pelaksanaannya tergantung pada ketersediaan tanah. UUPA juga memberikan perhatian khusus terhadap kelompok masyarakat yang lemah dan termarjinalkan oleh kebijakan pertanahan pada masa sebelumnya. Tetapi pada masa Orde Baru, terjadi perubahan ideologi pembangunan dari sosialisme ala
Indonesia yang dikembangkan oleh Soekarnokearah kapitalismebeserta anak kandungnya berupa liberalisasi dan swastanisasi penguasaan dan pemanfaatan tanah. Pada masa reformasi terdapat upaya untuk menghidupkan kebijakan pertanahan yang mengembalikan keseimbangan seperti yang diinginkan UUPA. Namun demikian, kebijakan tersebut tidak cukup mendapatkan dukungan dari instansi sektoral lainnya termasuk oleh aparat penegak hukum.

b. Beberapa dampak politik hukum pertanahan terhadap perlindungan hak kepemilikan tanah masyarakat adalah:

1) Konflik kewenangan antar instansi pemerintah yang terkait dengan pertanahan yaitu BPN di satu pihak dengan Kementerian Kehutanan, Kementerian Pertanian dan kementerian terkait lainnya. Sumber konfliknya adalah perbedaan caradalammewujudkanamanah Pasal 33 ayat (3) UUD Negara RI 1945. Di satu pihak terdapat kebijakan yang mengembangkan cara pemerataan penguasaan dan pemanfaatan tanah untuk mewujudkan kemakmuran seluruh komponen rakyat, sedangkan yang lain mengembangkan cara 


\section{$\mathrm{R}_{\text {EuCnal }}^{\text {juTSVINDING }}$

konsentrasi penguasaan dan pemanfaatan tanah untuk mewujudkan arah politik hukum pertanahan tersebut;

2) terjadinya kesenjangan dalam penguasaan dan pemanfaatan sumberdaya alam berupa tanah. Ada sekelompok kecil subyek menguasai dan memanfaatkan tanah yang sangat luas/besar, namun sebagian besar warga masyarakat hanya menguasai dan memanfaatkan bagian sumberdaya yang relatif terbatas;

3) Tingkat kemiskinan di Indonesia masih tinggi;

4) terjadi konflik struktural pertanahan.

c. Alternatif yang ditawarkan untuk mengurangi atau bahkan meniadakan dampak negatif dari politik hukum pertanahan saat ini adalah mengembangkan politik hukum pertanahan yang "prismatik" dengan bersandar pada Prinsip keberagaman hukum dalam Kesatuan; Prinsip persamaan atas dasar ketidaksamaan; Prinsip mengutamakan keadilan dan kemanfaatan di atas kepastian hukum; Prinsip diferensiasi fungsi dalam keterpaduan.

\section{Saran}

a. Dalam rangka mengembangkan sistem hukum nasional ke depan perlu diadopsi prinsip-prinsip politik hukum pertanahan yang prismatik.

b. Perlu koordinasi dan penyamaan persepsi antar instansi pemerintah yang terkait dengan pertanahan yaitu BPN di satu pihak dengan Kementerian Kehutanan, Kementerian Pertanian dan kementerian terkait lainnya mengenai cara pemerataan penguasaan dan pemanfaatan tanah untuk mewujudkan kemakmuran seluruh komponen rakyat. 


\section{R Eunen HTSVINDING}

\section{DAFTAR PUSTAKA}

Berita Resmi Statistik No.45/07/Th XIII, Profil Kemiskinan Di Indonesia 2010, (Jakarta: Badan Pusat Statistik, 1 Juli 2010).

Budihardjo, Eko, Mitropolis atau Miseropolis, (Kompas, Sabtu 22 September 2007).

Departemen Penerangan RI, Pertanahan Dalam Era Pembangunan Indonesia, (Jakarta: Ditjen Agraria Departemen Dalam Negeri, 1982).

Ismail, Nurhasan, Perkembangan Hukum Pertanahan : Pendekatan Ekonomi-Politik, (JakartaYogyakarta: Huma dan Magister Hukum UGM, 2007).

Kasim, Ifdhal, Tanah Sebagai Komoditas : Kajian Kritis Atas Kebijakan Pertanahan Orde Baru, (Jakarta: ELSAM, 1996).

Khudori, Petani, Kemiskinan, dan Reforma Agraria (Kompas, 16 Maret 2007).

Kompas, 2008, Tajuk Rencana : Kasus dan Penggusuran, Sabtu 26 Januari.

Kompas, 2011, Kemiskinan Tampak Nyata, Senen, 15 Agustus.

Lucinda, Di Tengah Kepungan Bisnis Ritel, (Yogyakarta, Harian Bernas, 2010).

Mas'oed, Mohtar, Ekonomi dan Struktur Politik : Orde Baru 1966-1971 (Jakarta: LP3ES, 1989).

McAuslan, Patrick, Tanah Perkotaan dan Perlindungan Rakyat Jelata (Jakarta, PT Gramedia, 1986).

Rahardjo, Satjipto, Hukum Progresif : Penjelajahan Suatu Gagasan, (Majalah Newsletter, Kajian Hukum Ekonomi dan Bisnis, Nomor 59, Desember 2004).

The Jakarta Post, 2009, Palm Oil Problem : Plantation Companies in Conflict With Villagers, Tuesday, May, $19^{\text {th }}$.

Universitas Gadjah Mada, 2008, Ketimpangan Kepemilikan Aset Sebagai Penyebab kemiskinan, Portal UGM(C)UGM, Kontak Webmaster : webugm@ugm.ac.id.

Winoto, Joyo, Mandat Politik, Konstitusi dan Hukum Dalam Rangka Mewujudkan Tanah Untuk Keadilan dan Kesejahteraan Rakyat, (Bulaksumur - Yogyakarta, Kuliah Umum, Balai Senat Universitas Gadjah Mada, 2007).

Zulfadhli, H, 2009, Tanah Untuk Petani, tulisan yang disampaikan dalam Seminar Nasional HKTI "Reforma Agraria, Pelaksanaan otonomi Daerah, dan Penataan Ruang; lihat juga Iwan N. Selamat, Ketimpangan Struktur Agraria Indonesia, 2009. 